Rok XIV (2019) | 2 (28) | s. 95-105

https://doi.org/10.12797/LV.14.2019.28.06

Ewa Woźniak (1)

Uniwersytet Łódzki, Łódź

ewa.wozniak@uni.lodz.pl

\title{
CZEGO ZENON KLEMENSIEWICZ NIE NAPISAŁ 0 JĘZYKU POLSKIM W DWUDZIESTOLECIU MIĘDZYWOJENNYM, CZYLI DLACZEGO POTRZEBNE JEST NOWE OPRACOWANIE DZIEJÓW POLSZCZYZNY W LATACH 1918-1939
}

Słowa klucze: historia języka polskiego XX wieku, dwudziestolecie międzywojenne, Zenon Klemensiewicz

Keywords: history of Polish language $2 \mathrm{O}^{\text {th }}$ century, interwar period, Zenon Klemensiewicz

Lata 1918-1939 to ostatni przedział czasowy uwzględniony w Historii języka polskiego Zenona Klemensiewicza (1985). Włączenie dwudziestolecia do doby nowopolskiej na długo utrwaliło pozycję tego okresu w periodyzacji dziejów polszczyzny, co wynikało $\mathrm{z}$ rangi Klemensiewiczowskiej syntezy w literaturze historycznojęzykowej, a szczególnie dydaktyce uniwersyteckiej. Utartym przez Klemensiewicza torem podążył Bogdan Walczak, przyjmując w Zarysie dziejów języka polskiego podział na trzy epoki, z okresem międzywojennym potraktowanym jako część doby nowopolskiej (Walczak 1999) ${ }^{1}$. Podobnie postąpiła Irena Bajerowa, która od roku 1939 rozpoczęła redagowany przez siebie tom Język polski czasu drugiej wojny światowej (1996), a następnie autorski Zarys historii języka polskiego (2005), będący kontynuacją

1 Przegląd najważniejszych stanowisk dotyczących umiejscowienia lat 1918-1939 w periodyzacji historycznojęzykowej zawiera artykuł Dwudziestolecie międzywojenne w periodyzacji historycznojęzykowej - wizje i rewizje (Woźniak 2017). 
syntezy Klemensiewicza ${ }^{2}$. Konsekwencją takiego umiejscowienia międzywojnia w porządku periodyzacyjnym było jego ujmowanie jako końca pewnej epoki, okresu wygasających tendencji, kontynuacji dziedzictwa zaborowego, dziewiętnastowiecznego. Przykładem może być niedawno wydana książka Mirosławy Sagan-Bielawy o znamiennym (w tym kontekście) tytule Dziedzictwo pozaborowe. Społeczna świadomość językowa Polaków w Drugiej Rzeczypospolitej (2014).

Stosunkowo niewielki, w porównaniu $\mathrm{z}$ innymi przedziałami wyodrębnionymi w dobie nowopolskiej ${ }^{3}$, jest też w Historii języka polskiego Klemensiewicza zasób informacji o zewnętrznej i wewnętrznej sytuacji języka w pierwszym dwudziestoleciu niepodległości. Przyczyny takiego stanu rzeczy można by upatrywać w braku odpowiedniej perspektywy czasowej, zwłaszcza jeśli zważyć, że koncepcja i zarys opracowania (według świadectwa Bajerowej) powstały jeszcze przed II wojną światową (Bajerowa 1985: 11). Usprawiedliwieniem dla niepełnego i wybiórczego obrazu lat 1918-1939 w Klemensiewiczowskiej syntezie mogłoby być również niedopracowanie ostatniego tomu dzieła, którego autor sam nie zdążył przygotować do druku Warto także wziąć pod uwagę ówczesną fazę rozwoju dyscypliny, której „zagadnienia i założenia" dzięki koncepcji Klemensiewicza zaczęły się krystalizować w latach 50. XX w. (Klemensiewicz 1956). Nie można też moim zdaniem wykluczyć pobudek ideologicznych, zwłaszcza jeśli uwzględni się rangę pominiętych informacji.

Wśród aspektów niewątpliwie kluczowych dla sytuacji języka polskiego, choćby dla polityki językowej państwa, pominięty milczeniem został fakt wielonarodowości i wielojęzyczności Drugiej Rzeczypospolitej. Zaskakuje nieobecność tego wątku zwłaszcza podczas omawiania społeczno-politycznego podłoża języka w okresie $1918-1939^{5}$. Klemensiewicz wspomina tu jedynie o „organizowanym od podstaw szkolnictwie powszechnym” (Klemensiewicz 1985: 525), odnotowuje obfitość literatury metodycznej dotyczącej nauczania języka polskiego oraz publikacji o charakterze poprawnościowym, wymienia powstałe $\mathrm{w}$ dwudziestoleciu instytucje propa-

2 Takie ujęcie wynikało zapewne również z przekonania autorki, że „Rok 1939 kończy [...] dobę nowopolską, zwłaszcza że i zmiany granic polszczyzny upoważniają do postawienia na roku 1939 krańcowego punktu doby nowopolskiej" (Bajerowa 2005: 158).

3 Klemensiewicz w Historii języka polskiego wyodrębnia lata 1918-1939 jako część doby nowopolskiej, obok okresu stanisławowskiego, okresu 1795-1815, okresu 1815-1831 oraz okresu 1831-1918. Takie wewnętrzne rozczłonkowanie autor przyjął w\$2. Społeczno-polityczne i kulturalno-oświatowe podłoże rozwoju języka doby nowopolskiej. Z kolei w $\$ 4$. Stosunek do mowy ojczystej w dobie nowopolskiej podrozdział poświęcony dwudziestoleciu nosi tytuł W Polsce międzywojennej (Klemensiewicz 1985).

4 Pisze o tym Bajerowa w Przedmowie do drugiego wydania dzieła (Bajerowa 1985: 11). Dzięki Tadeuszowi Lewaszkiewiczowi znamy nazwisko recenzenta wydawniczego pierwszej i drugiej części Historii języka polskiego Klemensiewicza (Lewaszkiewicz 2018), nie wiadomo natomiast, kto recenzował do publikacji tom trzeci.

5 Zob. \$2. Społeczno-polityczne i kulturalno-oświatowe podłoże języka doby nowopolskiej, z wydzielonym graficznie i tematycznie p. 5. Okres 1918-1939 (Klemensiewicz 1985: 598-601). 
gujące miłośnictwo języka oraz literatury (ze szczególnym uwzględnieniem Polskiej Akademii Literatury, której projekt zgłosił Stefan Żeromski). Poza tym wspomniane zostaje radio jako środek komunikacji zyskujący na znaczeniu i wywierający wpływ na upowszechnianie wzorów wypowiedzi mówionej, zwłaszcza poprawnej i ujednoliconej wymowy (ibid.: 525-527). Wśród podmiotów zasłużonych dla podniesienia poziomu wykształcenia społeczeństwa Klemensiewicz wymienił „władze wojskowe i Polski Biały Krzyż [które - E.W.] wiele wysiłku włożyły w tępienie analfabetyzmu i krzewienie czytelnictwa wśród żołnierzy" (ibid.: 526) ${ }^{6}$. Niemal te same wątki podjął on $\mathrm{w} \$ 4$. Stosunek do mowy ojczystej $w$ dobie nowopolskiej w p. 5. W Polsce międzywojennej: znów podkreślił rolę radia (ibid.: 598-599), dwa obszerne akapity poświęcił działalności Żeromskiego (Snobizm i postęp oraz Projekt Akademii Literatury Polskiej), dwa kolejne - czasopismom poprawnościowym: „Językowi Polskiemu” i „Poradnikowi Językowemu” (ibid.: 599-601). Nieobecności tematu wielonarodowości i wielojęzyczności u Klemensiewicza nie tłumaczą więc również ograniczenia wynikające z konieczności syntetycznego ujęcia, skoro znalazło się w jego opracowaniu miejsce na powtórne przywołanie właściwie tych samych informacji. Zagadnienia te nie mieściły się w Klemensiewiczowskiej koncepcji historii języka polskiego.

Klemensiewicz, zawsze dużo miejsca poświęcający w swojej syntezie systemowi szkolnictwa, kreśląc obraz jego organizacji w dwudziestoleciu, słowem nie wspomina o szkołach z wykładowym językiem mniejszości etnicznych oraz o szkołach utrakwistycznych, które stanowiły ważny element edukacyjnego pejzażu epoki. Zaznaczyć należy, że placówki nauczania, w których językiem wykładowym (lub jednym z języków wykładowych) był język innej narodowości, nie stanowiły wówczas jakiegoś marginesu, który bez szkody dla ogólnego obrazu można było pominąć. Działały nie tylko szkoły prywatne tego typu, ale również państwowe - powoływanie i jednych, i drugich regulowały przepisy prawa ${ }^{7}$. Mniejszościowymi językami nauczania w szkołach państwowych, a więc utrzymywanych ze środków rządowych, były w Drugiej Rzeczypospolitej: język niemiecki, ukraiński, białoruski, litewski i czeski (Kornecki 1929: 8). O tym, że szkolnictwo innojęzyczne było znaczącą częścią systemu edukacji międzywojnia, świadczą liczby: w połowie dwudziestolecia niepodległości (lata 1927/1928) było ponad 660 publicznych szkół powszechnych z niemieckim językiem wykładowym (jako jedynym lub drugim), prawie 3 tys. z wykładowym lub współwykładowym językiem ukraińskim, 72 z językiem białoruskim (w tym w 26 wyłącznym), 48 z językiem litewskim oraz 17 szkół z językiem czeskim

6 Por. Walczak: „[...] władze wojskowe włożyły wiele wysiłku w tępienie analfabetyzmu i krzewienie czytelnictwa wśród żołnierzy" (Walczak 1988: 50).

7 Była to jedna z tzw. ustaw kresowych z 1924 r., która określała warunki tworzenia szkół z niepolskim językiem wykładowym (ruskim, białoruskim lub litewskim) na obszarach województw wschodnich, uzależniając taką ewentualność od liczby ludności deklarującej przynależność do mniejszości etnicznej (ponad 25\%) oraz od żądania rodziców (Ogonowski 200o: 96-97). 
(16 na Wołyniu i 1 w Poznańskiem) (Kornecki 1929). Jedynie nauczanie w jidysz oraz hebrajskim odbywało się tylko w szkołach prywatnych ${ }^{8}$.

Władze Drugiej Rzeczypospolitej popierały szkoły utrakwistyczne, czyli dwujęzyczne, które tworzone były zarówno na poziomie podstawowym, jak i średnim 9 . Jednak nauka w tych szkołach nie budziła społecznej akceptacji ani wśród mniejszości etnicznych, ani po stronie polskiej. Przez inne narodowości placówki dwujęzyczne, będące alternatywą dla szkół z mniejszościowym językiem wykładowym, były traktowane jako miejsca przymusowej polonizacji. Stronie polskiej trudno było z kolei zaakceptować fakt, że w 90\% utrakwistycznych szkół powszechnych edukacja w klasie pierwszej odbywała się w języku niepolskim. Sytuację tak diagnozował Stanisław Chruściel w broszurze Szkoła państwowa a mniejszości narodowe w Polsce i za granica z $1938 \mathrm{r}$.:

Zatem polskie dzieci zaraz u wejścia w progi państwowej szkoły w Polsce uczą się w województwach południowo-wschodnich po rusku, jakby uczęszczały do szkoły czysto ruskiej. Dopiero od kl. II-giej uczą się po połowie obowiązkowych godzin w języku polskim i drugim języku miejscowym (Chruściel 1938: 12).

Polacy niechętnie też posyłali dzieci do utrakwistycznych szkół średnich (Hibel 2014: 146). Problemem byli również nauczyciele dwujęzyczni, o czym z kolei wspomina Helena Obiezierska w pamiętniku Jedno życie prywatne na tle życia narodu polskiego w wieku XX. Autorka przedstawia

[...] dwoje młodych kowieńczuków, którzy przyjechali do Polski uczyć w państwowych szkołach polskich z językiem wykładowym litewskim, jakich w okolicach Dukszt było potrzeba. O nauczycieli Polaków, znających litewski było trudno [...] (Obiezierska 1995: 261).

Dwujęzycznych nauczycieli kształcono w utrakwistycznych seminariach nauczycielskich.

Charakterystyczne dla Polski międzywojennej pejzaże wielojęzyczności malują autorzy wspomnień z tego czasu, np. Tadeusz Olszański czy wspomniana wcześniej Obiezierska:

[...] w Stanisławowie było mnóstwo szkół i gimnazjów zarówno państwowych, jak i prywatnych. Przeważnie polskich, ale również ukraińskich, żydowskich, jedna niemiecka szkoła i gimnazjum przy gminie ewangelickiej. Żydzi mieli dwa gimnazja

8 Prawo szkolne z 1924 r. nie uwzględniało możliwości nauczania w szkołach państwowych w jidysz czy po hebrajsku. Większość dzieci żydowskich uczęszczała do szkół polskich. Ukłonem w stronę obywateli wyznania mojżeszowego było jedynie funkcjonowanie tzw. szabasówek, czyli szkół, w których nie prowadzono zajęć w soboty oraz święta żydowskie (Wiecki 2013: 196).

9 Ustawa szkolna z 1924 r. przewidywała utrakwizację wszystkich szkół średnich w województwach wschodnich, jednak - jak zaznacza Kornecki w publikacji z 1929 r. - „władze szkolne [...] dotychczas tego przepisu ustawy nie wykonały" (Kornecki 1929: 12). 
z językiem hebrajskim, kupiecką szkołę handlową i żeńską szkołę rzemieślniczą. Ukraińcy - aż cztery gimnazja oraz żeńskie seminarium nauczycielskie. We wszystkich tych szkołach prowadzono też naukę języka polskiego. Za to w polskich szkołach obowiązkowo uczono języka ruskiego, bo tak oficjalnie nazywano język ukraiński i tak miałem wpisane na świadectwie. Od drugiej klasy oprócz pisania po polsku uczyliśmy się mówienia oraz pisania po ukraińsku cyrylicą i to z bardzo dobrym rezultatem, bo wszyscy byliśmy obeznani z tym językiem. $Z$ wieloma rówieśnikami z sąsiedztwa i z ulicy od dawna mówiliśmy ze sobą na zmianę po polsku lub ukraińsku, dobrze się rozumiejąc (T. Olszański, Kresy kresów - Stanisławów, Warszawa 2008, s. 37, cyt. za: Sanojca 2013: 32).

[...] mnie parokrotnie delegowano na egzaminatorkę do prywatnych szkół żydowskich z częściowymi prawami szkół państwowych. Były to seminaria nauczycielskie - jedno im. dr Czarno z językiem wykładowym żydowskim, drugie „Tarbut” z językiem hebrajskim. [...] Tam na egzaminie ustnym delegatem Ministerstwa był wyjątkowo - jako wyjątkowy w Polsce znawca hebrajskiego języka - sędzia Sądu Najwyższego, Rudolf Fleszyński. [...] Z historii i nauki o Polsce egzaminował sympatyczny kolega z Seminarium Nauczycielskiego [...] (Obiezierska 1995: 345).

Zastosowana w Historii języka polskiego strategia przemilczania problemów narodowościowych skutkuje pominięciem również faktu istnienia polskich mniejszości poza granicami niepodległej ojczyzny. Dla porównania - całkiem obszerne dwa akapity poświęca temu zagadnieniu Walczak najpierw w popularnonaukowym artykule Znaczenie odzyskania niepodległości $w$ dziejach języka polskiego, opublikowanym na łamach pisma „Życie i Myśl” (Walczak 1988: 55), a następnie w Zarysie dziejów języka polskiego (Walczak 1999: 227).

Poza obszarem zainteresowań Klemensiewicza znalazły się również prawne działania władz Drugiej Rzeczypospolitej regulujące zakres użycia języka polskiego w sferze publicznej. Największe znaczenie miała ustawa z 31 lipca 1924 r., nadająca polszczyźnie status języka państwowego. Ustawę tę poprzedziły akty prawne różnego szczebla wprowadzające język polski jako jedyny język obowiązujący w pracach parlamentu, język wykładowy w szkołach wyższych i język administracji szkolnej w placówkach nauczania wszelkiego typu. Języki mniejszości etnicznych (niemiecki, ukraiński, białoruski, litewski) zostały dopuszczone na określonych warunkach (pomocniczo) w sądownictwie, w szkolnictwie (o czym już była mowa), a także np. „przy kolejowych kasach biletowych i przy okienkach pocztowych” (Zieleniewski 1930: 30). Pominięty przez Klemensiewicza temat ustawodawstwa językowego, mimo że bez wątpienia znaczący dla „społeczno-politycznych” uwarunkowań rozwoju języka, a także obrazujący „stosunek do mowy ojczystej”, w konsekwencji przez długi czas pozostawał nieobecny w opracowaniach historycznojęzykowych.

$\mathrm{Na}$ brak zainteresowania tą problematyką zwracał jeszcze całkiem niedawno uwagę Władysław Lubaś w artykule O polskiej polityce językowej (Lubaś 2012: 14). Długo utrzymującą się lukę wypełniły dopiero w ostatnich latach opracowania 
M. Sagan-Bielawy Status prawny polszczyzny w odbudowywanym państwie polskim (lata 1916-1924) (Sagan-Bielawa 2012) i Ewy Woźniak Polityka językowa państwa polskiego w okresie międzywojennym (Woźniak 2015), a także Katarzyny Hibel „Wojna na mapy”, „wojna na słowa”. Onomastyczne i międzykulturowe aspekty polityki językowej II Rzeczpospolitej w stosunku do mniejszości ukrainskiej w Galicji Wschodniej w okresie międzywojennym (Hibel 2014). Zaangażowanie władz państwowych w politykę językową, mające także wymiar prawny, warte jest podkreślenia jako novum w warunkach rozwoju języka narodowego. Jest to czynnik stanowiący o odmienności lat 1918-1939 w stosunku do epoki poprzedzającej.

Mniejszy ciężar gatunkowy niż pominięcie faktu wielonarodowości i wielojęzyczności Drugiej Rzeczypospolitej oraz ich konsekwencji w postaci szkół z mniejszościowym językiem wykładowym oraz dwujęzycznych (utrakwistycznych) ma zarzut nietrafności niektórych diagnoz - co oczywiście zawsze może się zdarzyć (nawet największym autorytetom), zwłaszcza gdy nie jest możliwe zachowanie odpowiedniej perspektywy czasowej. Nietrafność diagnozy widać zwłaszcza na przykładzie opinii dotyczącej rozwoju leksyki: według Klemensiewicza zmiany w słownictwie w dwudziestoleciu nie objęły jego „trzonu” i miały przede wszystkim podłoże regionalne ${ }^{10}$ (Klemensiewicz 1985: 496). Być może autorytet Klemensiewicza spowodował zignorowanie okresu międzywojennego w badaniach tzw. nowej leksyki polskiej. Przyjęto błędne założenie, że można te badania rozpocząć od 1945 r. z pominięciem „epizodu” dwudziestolecia. W konsekwencji za powstałe po II wojnie światowej uznawano wyrazy o genezie międzywojennej. Zauważył to Jan Wawrzyńczyk, który w latach 9o. ubiegłego wieku postulował zrewidowanie sądów o „nowości” wielu jednostek (Wawrzyńczyk 1990, 1994, 1999). Skalę rozbieżności w ocenie ujawniło monumentalne Depozytorium leksykalne jezyka polskiego Piotra Wierzchonia (Wierzchoń 2010, 2014).

Zasób wiadomości o funkcjonowaniu polszczyzny w latach 1918-1939 jest więc w syntezie Klemensiewicza bardzo ograniczony. W niniejszym opracowaniu zwrócono uwagę przede wszystkim na braki w charakterystyce „społeczno-politycznego podłoża rozwoju języka”, zwłaszcza pomijanie kwestii wielonarodowości i wielojęzyczności. To, że pomimo istniejących luk Historia języka polskiego uznawana jest za opracowanie zawierające „chyba najpełniejszy i wszechstronny opis polszczyzny dwudziestolecia" (Sagan-Bielawa 2014: 20), świadczy o potrzebie stworzenia nowej syntezy dziejów polszczyzny tego okresu, która rekompensowałaby najbardziej dotkliwe braki. Postulat jest jednak trudny do zrealizowania ze względu na stosunkowo niewielki udział tego okresu w przekroju badań historycznojęzykowych.

Na małym zainteresowaniu historyków języka latami 1918-1939 zaważyła być może etykieta dwudziestolecia jako okresu kończącego poprzednią epokę. Wniosek

10 Por. „Wyraźniejsze są zmiany w zasobach leksykalnych, ale nie dotyczą trzonu słownictwa i w znacznej mierze są uwarunkowane regionalnie" (Klemensiewicz 1985: 496). 
taki nasuwa się tym bardziej, że literatura przedmiotu w tej dziedzinie znacząco ustępuje opracowaniom z zakresu historii, prasoznawstwa, socjologii, zarówno tych sprzed 1989 r., jak i nowszych. W stosunkowo niewielkim dorobku historycznojęzykowym zwraca uwagę ograniczona podstawa materiałowa. Źródłem wiedzy o polszczyźnie dwudziestolecia są bowiem przede wszystkim międzywojenne czasopisma i inne publikacje popularyzujące wiedzę o języku, głównie „Poradnik Językowy” czy "Język Polski”. Siłą rzeczy ukształtowały one obraz dość jednostronny, zdominowany przez perspektywę „miłośnictwa języka”, uprawianego nie tylko przez grono specjalistów - językoznawców, koncentrujących się na działalności popularyzatorskiej oraz eksperckiej, ale także przez amatorów, którym pisma oraz wydawnictwa chętnie udostępniały swoje łamy.

Wśród językoznawców monopol na tego rodzaju wypowiedzi miał Adam Antoni Kryński. Jego opinie wielokrotnie przywołuje w artykule poświęconym „społecznej świadomości Polaków" Sagan-Bielawa, kolejne strony uzmysławiają częstotliwość cytowania (Sagan-Bielawa 2017: 213, 216, 217, 219, 221 itd.). O aktywności Kryńskiego na łamach „Poradnika Językowego” świadczy indeks autorski w poświęconym historii „Poradnika...” opracowaniu Jerzego Tredera (Treder 1972: 33), rejestrującym 24 jego wypowiedzi z lat 1919-1931 ${ }^{11}$. Kryński był również autorem artykułów w „Tygodniku Ilustrowanym", na którego podstawie Monika Gabryś-Sławińska omawia stosunek do języka w dwudziestoleciu (Gabryś-Sławińska 2016: 286). Jego wypowiedzi na temat języka znajdziemy w „Gazecie Policyjnej i Administracyjnej” ${ }^{12}$, „Niwie”, „Wędrowcu”, „Ateneum”, „Kurierze Warszawskim” oraz „Bibliotece Warszawskiej” (Szober 1934: XIII). Jako „rzeczoznawca językowy” był Kryński członkiem Komisji Językowej Ministerstwa Komunikacji (wraz z Kazimierzem Królem) ${ }^{13}$.

Krąg osób, których wypowiedzi kształtują obraz polszczyzny międzywojnia, jest więc w istocie bardzo wąski. Do Kryńskiego dołączyć by można jeszcze Antoniego Krasnowolskiego, Jana Łosia, Andrzeja Gawrońskiego czy felietonistę Stanisława Wasylewskiego ${ }^{14}$. Konsekwencją bazowania na informacjach z bardzo ograniczonej liczby źródeł może być niewłaściwe rozłożenie akcentów czy nieobiektywna hierarchizacja osiągnięć. W nielicznych opracowaniach historycznojęzykowych zwraca uwagę nie tylko odwoływanie się do metajęzykowych wypowiedzi wąskiej reprezentacji autorów, ale również operowanie tymi samymi egzemplifikacjami. Takim

11 Por. także on-line: poradnik-jezykowy.uw.edu.pl (dostęp: 20 XII 2018).

12 Kazimierz Król w książeczce Wskazówki językowe do tekstu wydawnictw urzędowych wymienia „doskonale redagowaną” "Gazetę Policyjną i Administracyjną”, „korzystającą głównie ze współpracownictwa prof. A. Kryńskiego" (Król 1928: 10).

13 Por. Rozporządzenie.

14 Na wypowiedzi dwu ostatnich, czyli Gawrońskiego i Wasylewskiego, powołuje się choćby Sagan-Bielawa w artykule Wspólnota komunikacyjna na ziemiach polskich po odzyskaniu niepodległości (Sagan-Bielawa 2013: 44), dowcipnymi uwagami Wasylewskiego okrasza swój wykład Walczak (1999: 224). 
powracającym przykładem jest choćby opis dokonań Karolów Stadtmüllerów (ojca i syna) w dziedzinie inwentaryzowania i polonizowania terminologii technicznej i rzemieślniczej (Gajda 1976; Bajerowa 1982: 38; Klemensiewicz 1985: 630; Walczak 1999: 243). Działalność Stadtmüllerów została spopularyzowana na łamach „Poradnika Językowego" przez syna, który był osobiście zaangażowany w reaktywowanie pisma w 1929 r. (Treder 1972: 7), indeks autorski w opracowaniu Tredera rejestruje 13 jego wypowiedzi. Mniej znane są prace innych gremiów, a na opracowanie czekają tematy kształtowania się polskiej terminologii wielu różnych dziedzin, m.in. sportowej ${ }^{15}$, radiowej czy motoryzacyjnej ${ }^{16}$. O dynamice rozwoju słownictwa specjalistycznego w okresie dwudziestolecia można się przekonać, przeglądając Depozytorium leksykalne Wierzchonia (2014).

Z. Klemensiewicz w swoim dziele pominął szereg istotnych treści dotyczących zewnętrznej (zwłaszcza) i wewnętrznej historii polszczyzny w Polsce międzywojennej. A przecież wydawać by się mogło, że ze względu na radykalną zmianę w funkcjonowaniu języka po odzyskaniu niepodległości okres ten, mimo że zaledwie dwudziestoletni, domagał się większego z jego strony zainteresowania. Przede wszystkim pominięte zostały kwestie łączące się z wielonarodowością i wielojęzycznością Drugiej Rzeczypospolitej. Nie wspomina też Klemensiewicz o zagadnieniach mieszczących się w obrębie polityki językowej państwa. Nie znajdziemy u niego wzmianki o ówczesnym ustawodawstwie językowym. Oczywiście nie sposób uznać, że takie fakty, jak przyznanie polszczyźnie statusu języka państwowego w akcie prawnym, ocenione zostały przez tego uczonego jako nieistotne dla społeczno-politycznych uwarunkowań rozwoju języka.

Nie wydając wyroku co do przyczyn takiego stanu rzeczy, skonstatować należy potrzebę nowego opracowania dziejów polszczyzny w międzywojniu, które wypełniłoby istniejące luki. W nowej syntezie powinno się również uwzględnić metodologiczne zdobycze historii języka z ostatnich dziesiątków lat.

Postulować należy ponadto rozszerzenie podstawy materiałowej w historycznojęzykowych badaniach dwudziestolecia, ponieważ - to właściwie truizm - bazowanie na jednym typie źródeł prowadzi do uzyskania obrazu niekompletnego, a nawet wypaczonego. Drzemiący tu potencjał odkrywczy potwierdza penetracja prasy międzywojennej, prowadzona z myślą o odtworzeniu zaginionego w czasie II wojny światowej suplementu do Stownika warszawskiego. Wielotomowy fotosuplement do tego słownika, opracowany przez Wierzchonia, daje wyobrażenie o dokonujących się w tym krótkim okresie przełomowych zmianach w zasobach leksykalnych pol-

15 Por. „Mimo pojawiających się co pewien czas uwag i analiz dotyczących niespójności języka sportowego nie udało się w latach dwudziestych wieku XX ustalić kanonu słownictwa fachowego. [...] Temat kształtowania się takiego kanonu jest ciekawą propozycją badawczą" (Siekiera 2016: 56).

16 Opracowanie Anny Starzec poświęcone polskiej terminologii motoryzacyjnej zawiera omówienie słownictwa jedynie wybranych grup leksykalno-semantycznych, wśród których brakuje choćby nazw samochodu w ogóle, miejsc jego tankowania czy postoju (Starzec 1984). 
szczyzny, zwłaszcza, jak się wydaje, przyroście słownictwa terminologicznego (ibid.). Z kolei rekonesansowe badania międzywojennych pamiętników ówczesnych prominentów pod kątem leksyki odnoszącej się do organów władzy i ich funkcjonowania dowiodły, że właściwie już w latach 20. ukształtowało się nieoficjalne nazewnictwo z zakresu parlamentaryzmu, w znacznym stopniu kontynuowane we współczesnej polszczyźnie (Woźniak 2019).

Konieczne wreszcie jest, jak sądzę, nadanie okresowi 1918-1939 właściwej rangi w historycznojęzykowym porządku periodyzacyjnym poprzez traktowanie go jako początku nowej epoki w dziejach polszczyzny.

\section{Literatura}

BAjerowa I., 1982, Badania nad terminologia języków specjalnych (środowiskowych), [w:] J. Rieger, M. Szymczak (red.), Język i językoznawstwo polskie w sześćdziesięcioleciu niepodległości (1918-1978). Materiały konferencji naukowej, Warszawa, 25 października 1978, Wrocław, s. 37-40.

Bajerowa I., 1985, Przedmowa, [w:] Z. Klemensiewicz, Historia języka polskiego, cz. 1: Doba staropolska (od czasów najdawniejszych do początków XVI wieku), „Z Prac Instytutu Badań Literackich PAN”, Warszawa, s. 11-12.

BAjerowa I. (red.), 1996, Język polski czasu drugiej wojny światowej (1939-1945), Warszawa. BAJEROWA I., 2005, Zarys historii jezzyka polskiego 1939-200o, Warszawa.

Chruściel S., 1938, Szkoła państwowa a mniejszości narodowe w Polsce i za granica, Lwów.

GABRYś-SŁAWIŃsKa M., 2016, Język jako wartość w „Tygodniku Ilustrowanym” w latach 19181929, „LingVaria” nr 2 (22), s. 279-292, [on-line:] http://dx.doi.org/10.12797/LV.11.2016.22.18.

Gajda S., 1976, Rozwój polskiej terminologii górniczej, „Studia i Monografie WSP im. Powstańców Śląskich w Opolu”, nr 55, Opole.

Hibel K., 2014, „Wojna na mapy”, „wojna na słowa”. Onomastyczne i międzykulturowe aspekty polityki językowej II Rzeczpospolitej w stosunku do mniejszości ukraińskiej w Galicji Wschodniej w okresie międzywojennym, „Slavische Sprachgeschichte”, t. 7, Wien - Berlin.

KlemensiewiCz Z., 1956, Zagadnienia i założenia historii języka polskiego, „Pamiętnik Literacki” XLVII, s. 86-137.

Klemensiewicz Z., 1985, Historia języka polskiego, cz. 3: Doba nowopolska (od ósmego dziesięciolecia XVIII wieku do r. 1939), „Z Prac Instytutu Badań Literackich PAN”, Warszawa.

Kornecki J., 1929, Szkolnictwo dla mniejszości narodowych w Polsce, Warszawa.

KRóL K., 1928, Wskazówki językowe do tekstu wydawnictw urzędowych: 1. „Konstytucja Rzeczypospolitej Polskiej”, 2. „Dziennik Urzędowy Min. Wyznań Religijnych i Oświecenia Publicznego", Warszawa.

LEWASZKIEWICZ T., 2018, Władysław Kuraszkiewicz jako recenzent wydawniczy Historii języka polskiego Zenona Klemensiewicza, [w:] M. Hawrysz, M. Uździcka (red.), Wokót dziejów używania polszczyzny - wspólnoty, potrzeby, zachowania komunikatywne, „Zielonogórskie Seminaria Językoznawcze”, 2017, Zielona Góra, s. 211-224.

Lubaś W., 2012, O polskiej polityce językowej, „Poradnik Językowy” nr 6, s. 11-33.

OBIEZIERsKa H., 1995, Jedno życie prywatne na tle życia narodu polskiego w wieku XX, „Biblioteka Wileńskich Rozmaitości”. Seria B, nr 4, Bydgoszcz. 
Ogonowski J., 2000, Uprawnienia językowe mniejszości narodowych w Rzeczypospolitej Polskiej 1918-1939, Warszawa.

RozporząDzenie: Rozporządzenie Ministra Komunikacji z dnia 13 grudnia 1930 r. Nr. I/1/11239/30 w sprawie Regulaminu Komisji Językowej Ministerstwa Komunikacji oraz składu osobowego tej Komisji, Dziennik Urzędowy Ministerstwa Komunikacji 1931, nr 1, poz. 1, [on-line:] https://jbc.bj.uj.edu.pl/dlibra/publication/375233/edition/357418/ content (dostęp: 20 XII 2018).

SAGAN-Bielawa M., 2012, Status prawny polszczyzny w odbudowywanym państwie polskim (lata 1916-1924), „Socjolingwistyka” XXVI, s. 107-121.

Sagan-Bielawa M., 2013, Wspólnota komunikacyjna na ziemiach polskich po odzyskaniu niepodległości, [w:] P. Nowakowski, K. Stroński, M. Szczyszek (red.), Wspólnoty komunikacyjne, „Poznańskie Spotkania Językoznawcze”, t. 25, s. 39-46.

Sagan-Bielawa M., 2014, Dziedzictwo pozaborowe. Społeczna świadomość językowa Polaków w Drugiej Rzeczypospolitej, „Biblioteka LingVariów”, t. 18, Kraków.

Sagan-Bielawa M., 2017, Język jako element świadomości społecznej (na przykładzie Polski po 1918 roku), „LingVaria” nr 2 (12), s. 211-223, [on-line:] http://dx.doi.org./10.12797/ LV.12.2017.24.14.

SANOJCA K., 2013, Dwa patriotyzmy, czyli rzecz o wychowywaniu polskiej i ukraińskiej młodzieży na Kresach Południowo-Wschodnich Drugiej Rzeczypospolitej, [w:] A. Landau-Czajka, K. Sierakowska (red.), Procesy socjalizacji w Drugiej Rzeczypospolitej 1914-1939. Zbiór studiów, „Metamorfozy Społeczne”, 7, Warszawa, s. 19-34.

Siekiera R., 2016, Początki polskiej publicystyki sportowej w ujęciu genologicznym. „Przeglad Sportowy” w latach 1921-1925, „Dziennikarstwo i Komunikacja”, Łódź.

STARzEC A., 1984, Rozwój polskiej terminologii motoryzacyjnej (od początku do 1945 roku), „Studia i Monografie WSP im. Powstańców Śląskich w Opolu”, nr 94, Opole.

Szober S., 1934, Adam Antoni Kryński. Życie i prace, Warszawa, s. VII-XXXIX (odb. z „Prac Filologicznych” XVI), [on-line:] http://pbc.biaman.pl/dlibra/docmetadata?id=32529 (dostęp: 20 XII 2018).

Treder J., 1972, 7o lat „Poradnika Językowego”. Zawartość pisma w latach 1901-1970, Warszawa.

WalczaK B., 1988, Znaczenie odzyskania niepodległości $w$ dziejach języka polskiego, „Życie i Myśl” 36, nr 10, s. 44-55.

WalczaK B., 1999, Zarys dziejów języka polskiego, Wrocław.

WAWRZYŃCZYK J., 1990, Nowe słownictwo polskie w świetle źródeł prasowych z lat 1918-1939, Łódź.

WAWRZyŃCZyK J., 1994, Tak zwane nowe słownictwo polskie w świetle dokumentacji „Polskiego Informatorium Wyrazowego", Katowice.

WAWrZyŃCZyK J., 1999, Nowe słownictwo polskie. Fikcje i fakty, „Semiosis Lexicographica”, t. 2, Warszawa.

Wiecki E., 2013, Kim maja być nasze dzieci? Podręczniki do nauki języka żydowskiego dla dzieci najmłodszych, [w:] A. Landau-Czajka, K. Sierakowska (red.), Procesy socjalizacji w Drugiej Rzeczypospolitej 1914-1939. Zbiór studiów, „Metamorfozy Społeczne”, 7, Warszawa, s. 193-213.

Wierzchoń P., 2010, Depozytorium leksykalne języka polskiego. Nowe fotomateriały z lat 1901-2010, t. 1, Warszawa.

WierzChoń P., 2014, Depozytorium leksykalne języka polskiego. Fotosuplement do Słownika warszawskiego, t. 11-40, Warszawa. 
Woźniak E., 2015, Polityka językowa państwa polskiego w okresie międzywojennym, „Socjolingwistyka” XXIX, s. 7-20, [on-line:] http://dx.doi.org./10.17651/SOCJOLING.29.1.

WoźNIAK E., 2017, Dwudziestolecie międzywojenne w periodyzacji historycznojęzykowej wizje i rewizje, „Acta Universitatis Lodziensis. Folia Linguistica” 51, t. 2, s. 99-111, [on-line:] http://dx.doi.org/10.18778/0208-6077.51.2.08.

Woźniak E., 2019, Pamiętniki jako źródło do dziejów języka polskiego w okresie dwudziestolecia międzywojennego, „Poradnik Językowy” nr 4, s. 21-31.

Zieleniewski L., 1930, Ustawodawstwo językowe Rzeczypospolitej Polskiej, Warszawa.

\section{What Zenon Klemensiewicz Did Not Write About the Polish Language in the Interwar Period, or Why Is There a Need for a New Synthesis of the History of Polish Between 1918 and 1939 Summary}

The article formulates a postulate of a new synthesis of the history of the Polish language in the years 1918-1939, and presents reasons that justify this need. The interwar period has been described in the third volume of Z. Klemensiewicz's History of the Polish Language (Pol. Historia jezzyka polskiego) as the closing phase of the New Polish period. Such classification of this brief period in the history of Polish might be the reason why it has attracted little interest from historians studying the language, and why the centre of gravity of linguistic research has shifted to the period after 1945 which Klemensiewicz presented as the time of great changes in the Polish language. Klemensiewicz's work, whose third volume was published in 1974, ignores numerous important issues which characterize the sociopolitical background of the development of Polish and the attitude towards the language. These are primarily issues connected to multinationality and multilingualism, including the problem of bilingual education with the language of instruction being a minority language, and the question of language policy. A wider range of sources needs to be included in historical and linguistic research into the interwar period, as the existing literature is mainly only familiar with the topics popularized by contemporary language correctness journals such as Poradnik Językowy or Język Polski. 